\title{
Characterization and PUFA production of Aurantiochytrium limacinum BUCHAXM 122 isolated from fallen mangrove leaves
}

\author{
Khanoksinee Sirirak ${ }^{\mathrm{a}}$, Sudarat Suanjit ${ }^{\mathrm{b}}$, Sorawit Powtongsook ${ }^{\mathrm{c}, \mathrm{d}}$, Somtawin Jaritkhuan ${ }^{\mathrm{e}, *}$ \\ a Environmental Science Program, Faculty of Science, Burapha University, Chon Buri 20131 Thailand \\ b Department of Microbiology, Faculty of Science, Burapha University, Chon Buri 20131 Thailand \\ c Center of Excellence for Marine Biotechnology, Department of Marine Science, Faculty of Science, \\ Chulalongkorn University, Bangkok 10330 Thailand \\ d National Center for Genetic Engineering and Biotechnology, National Science and Technology \\ Development Agency, Pathum Thani 12120 Thailand \\ e Department of Aquatic Science, Faculty of Science, Burapha University, Chon Buri 20131 Thailand
}

*Corresponding author, e-mail: somtawin@buu.ac.th

Received 17 Jan 2020

Accepted 9 Jun 2020

\begin{abstract}
Aurantiochytrium limacinum BUCHAXM 122, a strain of thraustochytrid microorganism is potentially an alternative source of essential nutrients for commercial products. In this study, the strain was screened for its characterization and determination of polyunsaturated fatty acid (PUFA) production. Cells were isolated from fallen mangrove leaves, and grown in a glucose-yeast extract-peptone (GYP) medium. Their morphology, life cycle, biomass, fatty acid, extracellular enzymes and major elements were also investigated. Colonies occurred prominently on the fourth day of cultivation, appearing opaque white in color and containing large numbers of amoeboid cells. These thraustochytrids were observed to have a multi-stage life cycle, developing through zoospore, vegetative and zoosporangium stages with a life span of approximately $24 \mathrm{~h}$. Zoospores developed into vegetative cells within 10$12 \mathrm{~h}$ and vegetative cells developed into zoosporangia, releasing zoospores, within approximately 10-15 h. Results showed that $A$. limacinum BUCHAXM 122 produced highest biomass at $108 \mathrm{~h}$, with $23.85 \pm 1.02 \mathrm{~g} / \mathrm{l}$ dry weight. The isolates had high content of docosahexaenoic acid (DHA; $30.31 \pm 5.88 \%$ of total fatty acids), indicating that they could serve as a fatty acid source for human consumption and aquaculture feeds. Major elemental analysis showed that cells contained 57\% carbon, $29 \%$ oxygen, $9 \%$ hydrogen, $4 \%$ nitrogen and 1\% sulfur. Extracellular degradative enzymes including protease, lipase, urease, $\alpha$-glucosidase and phosphatase activities were also detected.
\end{abstract}

KEYWORDS: Aurantiochytrium limacinum, polyunsaturated fatty acids, DHA, extracellular enzyme

\section{INTRODUCTION}

Thraustochytrids are unicellular eukaryotic organisms normally found in mangrove forests, seagrasses and algae in coastal and oceanic regions throughout the world [1]. The species chosen in this study is a non-photosynthetic marine eukaryote that plays an important role in estuarine and marine ecosystems, due to its degradative abilities [2], which are integral for the microbial food web. Recently, thraustochytrids have been distinguished for their ability to produce high-value omega-3 polyunsaturated fatty acids (n-3 PUFA), particularly DHA (docosahexaenoic acid, 22:6n-3) and EPA (eicosapentaenoic acid, 20:5n-3). In addition, ALA ( $\alpha$ linolenic acid, 18:3n-3) and GLA ( $\gamma$-linolenic acid, 18:3n-6) are PUFAs that can be transformed into arachidonic acid (ARA, 20:4n-6), docosapentaenoic acid (DPA, 22:5n-3) and DHA [3]. These polyunsaturated fatty acids are known as key in physiological development of children and adults, with a preventive role for different pathologies, such as cardiovascular diseases, neural disorders, asthma, arthritis, skin diseases and a wide range of cancers [4]. Moreover, they also play an important role in aquaculture, for which thraustochytrids are currently used as an alternative fatty acid source.

Aurantiochytrium limacinum, a thraustochytrid strain, is likely an ideal alternative n-3 PUFA source. The DHA content of this species is approximately $1.43-29.67 \%$ of total fatty acids (TFA) [5]. For this reason, thraustochytrid production could be applied 
to industry demand for human food supplements and high quality animal feeds.

The relationship between growth and lipid accumulation was evaluated in this study at all growth phases [6], with emphasis on growth enhancement and production of extracellular enzymes [7]. Understanding the enzymes present can lead to identifying a novel substrate that benefits both the economy and the environment. Elemental balance of biomass and culture medium composition was of concern, in order to enhance growth capability in high-density cell cultures [8]. This study focused on biological characteristics of $A$. limacinum BUCHAXM 122 isolated from fallen leaves in a mangrove forest of Chanthaburi province, Thailand, using in vitro experiments. Each growth phase was investigated in order to determine the highest fatty acid production, and thus the appropriate harvest period.

\section{MATERIALS AND METHODS}

\section{Strains and cultivation}

Thraustochytrids, A. limacinum BUCHAXM 122 were isolated from fallen mangrove leaves at Mangrove Resources Development Station 2 Tha Son, Chanthaburi province, Thailand. They were initially grown in 250-ml Erlenmeyer flasks containing $50 \mathrm{ml}$ of glucose-yeast extract-peptone (GYP) liquid medium. Basal medium consisted of $60 \mathrm{~g} / \mathrm{l}$ glucose, $10 \mathrm{~g} / \mathrm{l}$ yeast extract and $10 \mathrm{~g} / \mathrm{l}$ peptone in $15 \mathrm{psu}$ seawater. Cultures were inoculated at $25^{\circ} \mathrm{C}$ with $200 \mathrm{rpm}$ for $48 \mathrm{~h}$. Then, the cells were sampled (50 $\mu \mathrm{l})$ and cell morphology was observed. The life cycle was monitored under microscope (Carl Zeiss ${ }^{\circledR}$ Primo Star, Germany) without staining, using $100 \times 10$ magnification.

\section{Biomass determination}

The pure cultures were maintained on a GYP agar medium containing glucose, yeast extract and peptone (each at $1 \mathrm{~g} / \mathrm{l}$ ), incubated at $29-32{ }^{\circ} \mathrm{C}$ for $96 \mathrm{~h}$. An inoculum was prepared by transferring a single colony of A. limacinum BUCHAXM 122 from a GYP agar plate to a 250-ml Erlenmeyer flask containing $50 \mathrm{ml}$ of GYP liquid medium. The inoculum was incubated at $25^{\circ} \mathrm{C}$, with shaking (200 rpm) for $48 \mathrm{~h}$. The cultivation was performed in 45 Erlenmeyer flasks $(250 \mathrm{ml})$ containing $50 \mathrm{ml}$ of culture medium. All flasks were inoculated with $5 \%$ inoculum (v/v) and incubated for $168 \mathrm{~h}$ at $25^{\circ} \mathrm{C}$ and $200 \mathrm{rpm}$. After $24 \mathrm{~h}$, cells from three culture flasks were harvested every $12 \mathrm{~h}$ to estimate biomass throughout the incubation period. All samples were asepti- cally removed from the flasks, transferred into a 50-ml tube, and centrifuged at $13420 \times g$ at $4^{\circ} \mathrm{C}$ for $30 \mathrm{~min}$. The supernatant liquid was carefully removed, with the cell sedimentation then freezedried at $-80^{\circ} \mathrm{C}$, (using freeze-dryer Heto LyoLab 3000, Heto-Holten A/S, Allerød, Denmark). The dried cells were weighed and expressed as $g / 1$ to determine dry biomass. Average dry cell weight at each $12 \mathrm{~h}$ was plotted to create a growth curve. Specific growth rate was determined from the slope of a semi-logarithmic plot of dry biomass versus time, while maximum specific growth rate in batch was detemined from a linear regression.

\section{Lipid extraction and fatty acid composition analysis}

After the dried cells were weighed for biomass determination, they were analyzed using direct transesterification method, modified from Shimizu et al [9]. Lipids from freeze-dried cells (0.1-2.0 g) were extracted by adding $4 \mathrm{ml}$ sulfuric acid/methanol mixture $(2: 100, \mathrm{v} / \mathrm{v})$ and $200 \mu \mathrm{l}$ of internal standard (nonadecanoic acid, 19:0, Fluka, Buchs, Switzerland), flushed with nitrogen gas, and then heated at $80^{\circ} \mathrm{C}$ in a water bath for $2 \mathrm{~h}$. The extracted fatty acid methyl esters (FAME) were analyzed using gas chromatography (HP 6890 Series GC System, Wilmington, DE, USA) equipped with a flame ionization detector (FID) and a capillary column HP-INNO Wax polyethylene glycol $(60 \mathrm{~m} \times 250 \mu \mathrm{m} \times 0.25 \mu \mathrm{m})$. Helium was used as the carrier gas. Both detector and injector temperatures were set at $250^{\circ} \mathrm{C}$. Column temperatures were initially programmed to be $50^{\circ} \mathrm{C}$ for $1 \mathrm{~min}$, increasing at a rate of $50^{\circ} \mathrm{C} / \mathrm{min}$ to $200^{\circ} \mathrm{C}$, and holding for $1 \mathrm{~min}$; then increasing by $2^{\circ} \mathrm{C} / \mathrm{min}$ to $210^{\circ} \mathrm{C}$, and holding for $14 \mathrm{~min}$. Peak identification was performed by means of retention time of known standard fatty acids (Sigma Chemical Co., St. Louis, MO, USA). Fatty acid contents were calculated according to peak area of chromatogram, in accordance with the internal standard.

\section{Investigation of extracellular enzymes produced by A. limacinum BUCHAXM 122}

Pure cultures of $A$. limacinum BUCHAXM 122 were maintained on GYP agar plates at $29-32{ }^{\circ} \mathrm{C}$ for 4 days before starting ten extracellular enzyme assays. Assays of activity of six enzymes, namely agarase, cellulase, xylanase, amylase, protease and lipase were done, using methods modified from Rajeswari et al [10]; Gorems and Alemu [11]; SaeLee [12]; Singh et al [13]; Nadeem et al [14] 
and Rai et al [15], respectively. Qualitative assays were carried out by point inoculation on nutrient agar plates impregnated with respective substrates and 3\% sodium chloride. Substrates for agarase, cellulase, xylanase, amylase, protease and lipase activity determination were agarose medium, carboxymethyl cellulose (CMC) agar, xylan agar, starch agar, skim milk agar and Tween 80 agar, respectively. After incubation at $29-32{ }^{\circ} \mathrm{C}$ for $24-168 \mathrm{~h}$, production of the six enzymes was observed as a clear zone around the colonies. Specific reagents for detecting agarase and cellulase were Lugol's iodine and Congo red, respectively; the specific reagent for detecting both xylanase and amylase was Gram's iodine.

Activity of $\alpha$-glucosidase was determined using a method modified from Arellano and Olmos [16]. Colonies of A. limacinum BUCHAXM 122 were initially grown in 250-ml Erlenmeyer flasks, containing $50 \mathrm{ml}$ of the GYP medium at $25^{\circ} \mathrm{C}$ and shaken at $200 \mathrm{rpm}$ for $96 \mathrm{~h}$. After that, the medium was centrifuged, and $20 \mu \mathrm{l}$ of the supernatant was mixed with $100 \mu$ l of pNPG (p-nitrophenyl- $\alpha$-Dglucopyranoside) and $730 \mu \mathrm{l}$ of $10 \mathrm{mM}$ phosphate buffer (pH 7) in a 10-ml glass tube. The solution was incubated at $37^{\circ} \mathrm{C}$ for $12 \mathrm{~h}$ and the reaction was terminated by adding $150 \mu \mathrm{l}$ of sodium carbonate $(2 \% \mathrm{w} / \mathrm{v})$. The $\alpha$-glucosidase activity was indicated by a color change from clear to pale yellow.

The presence of phosphatase and urease were determined according to the procedures of Barrow and Feltham [17] and Vuye and Pijck [18], respectively. Colonies of $A$. limacinum BUCHAXM 122 were initially grown on GYP agar plates at $29-32^{\circ} \mathrm{C}$. After $96 \mathrm{~h}$, the colonies were transferred to phenolphthalein phosphate agar plates by point inoculation, and incubated at $29-32^{\circ} \mathrm{C}$ for $96 \mathrm{~h}$. A drop of ammonia solution was then placed on each colony, and any color changes were observed. If the colony color turned pink, it indicated the presence of phosphatase. The test for urease was done by transferring colonies into 27-ml tubes containing $10 \mathrm{ml}$ of Christensen urea agar slant. The test basis is the ability of A. limacinum BUCHAXM 122 to secrete urease, which catalyzes conversion of urea to ammonia and carbon dioxide. This result raises $\mathrm{pH}$ of the medium, and changes the color of the specimen from yellow to red.

The presence of gelatinase was determined according to the procedure of Harley and Prescott [19]. A. limacinum BUCHAXM 122 was inoculated by stabbing $50 \mu \mathrm{l}$ of inoculum into a tube containing nutrient gelatin medium.
Table 1 Morphological features of $A$. limacinum BUCHAXM 122 grown on GYP agar.

\begin{tabular}{ll}
\hline Character & Colony morphology \\
\hline Colony morphology & $\begin{array}{l}\text { Colonies opaque white, } \\
\text { irregularly spread in form, } \\
\text { undulate margin and } \\
\text { flat elevation }\end{array}$ \\
& $2-4 \mathrm{~mm}$ \\
Size of colony & Thin-walled \\
Cell wall & Present \\
Amoeboid cells & Spherical, $\varnothing=5-10 \mu \mathrm{m}$ \\
Shape and size of vegetative cell & Spherical, $\varnothing=6-25 \mu \mathrm{m}$ \\
Shape and size of zoosporangium & Present \\
\hline Binary cell division & \\
\hline
\end{tabular}

Inoculated tubes were kept in an incubator at $4{ }^{\circ} \mathrm{C}$ for $96-168 \mathrm{~h}$, and checked daily for gelatin liquefaction. Gelatin normally liquefies at $28^{\circ} \mathrm{C}$ and above; liquefaction at the lower temperature of the test is assumed to be the result of gelatinase activity.

\section{Elemental analysis}

Quantification of the major elements (carbon (C), hydrogen $(\mathrm{H})$, nitrogen $(\mathrm{N})$, oxygen $(\mathrm{O})$ and sulfur (S)) in relation to dry biomass was performed in an elemental analyzer (LECO, CHN628, 628S, TruSpec Micro O, Saint Joseph, MI, USA), complying with the ASTM D5373 standard, at Laboratory Service Unit: LSU, Suranaree University of Technology, Thailand.

\section{RESULTS}

\section{Morphological characteristics}

On GYP medium, colonies of A. limacinum BUCHAXM 122 appeared prominently on the fourth day of cultivation, opaquely white, with flat elevation and undulating margins (Fig. 1a-b). Their morphology is summarized in Table 1 and Fig. 1. Vegetative cells were spherical in shape and mostly dispersed as single cells (Fig. 1c); however, some vegetative cells were undergoing repeated binary division, and forming small clusters (Fig. 1d). Binary cell division (Fig. 1e), amoeboid cells (Fig. 1f) and release of zoospores (Fig. 1g-h) were observed.

The life cycle of A. limacinum BUCHAXM 122 was quite short, approximately $24 \mathrm{~h}$. They have a multi-stage life cycle, developing through zoosporic, vegetative and zoosporangium stages (Fig. 2). Zoospores were released from parental cells, then observed swimming briefly, using two flagella, for approximately $1 \mathrm{~h}$ (Fig. 2a). When swimming activity terminated, the zoospores began to develop into vegetative cells, taking approximately $10-12 \mathrm{~h}$ to develop from settled zoospores 

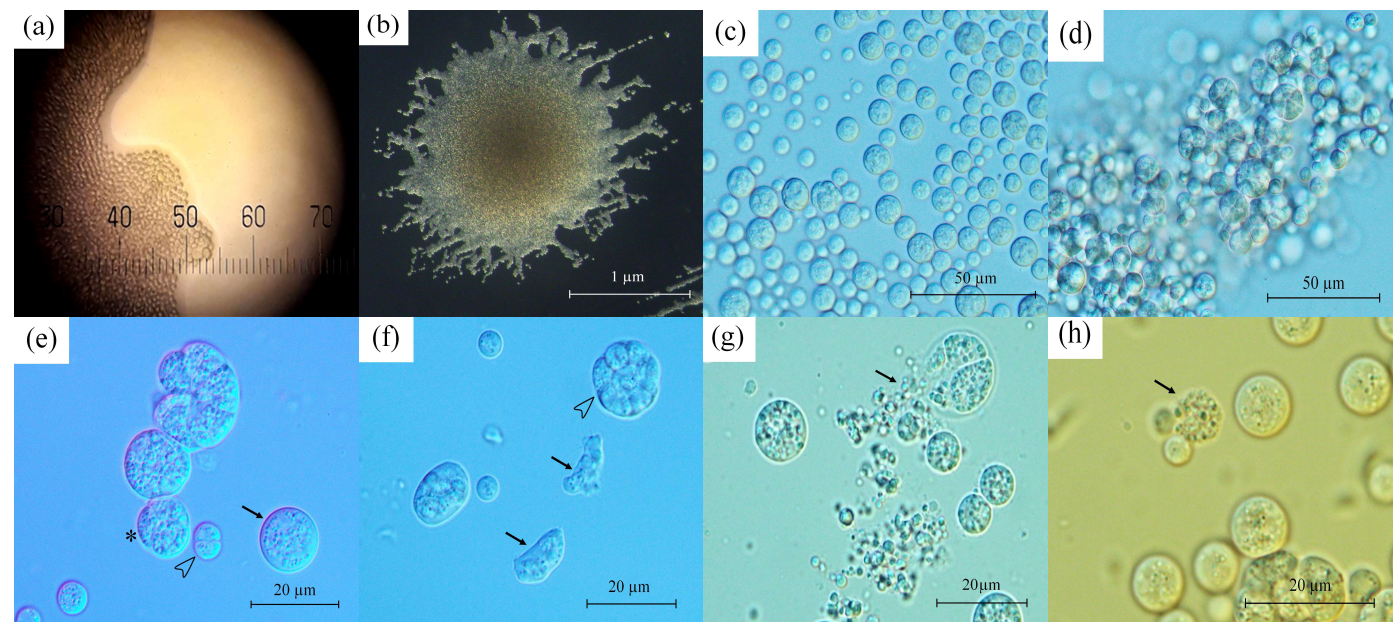

(g)

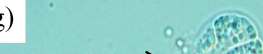

(h)

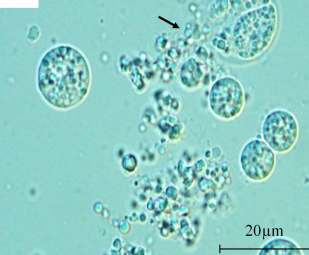

(1)

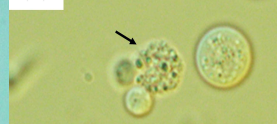

Fig. 1 Colony morphology and cells of A. limacinum BUCHAXM 122 grown on GYP for $96 \mathrm{~h}$. (a,b) colony margin and a single colony on GYP agar; (c) dispersion of vegetative cells; (d) cluster of cells; (e) vegetative cell (arrow), diad (arrowhead), tetrad (asterisk); (f) octad (arrowhead), amoeboid cells (arrows); (g) release of zoospores from small opening in zoosporangium wall (arrow); (h) cell wall of zoosporangium appears to become loose (arrow).

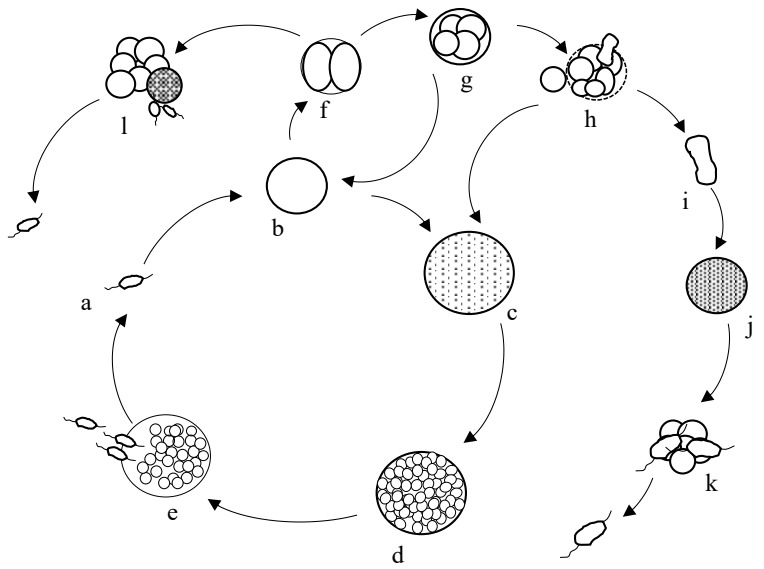

Fig. 2 Life cycle of A. limacinum BUCHAXM 122 . (a) zoospore; (b) a single vegetative cell; (c) size of vegetative cell increases and division occurs; (d) mature zoosporangium containing zoospores; (e) zoosporangium walls split or tear, and release zoospores; (f) binary division, diad; $(\mathrm{g}$ ) binary division, tetrad; (h) release of amoeboid cell; (i) amoeboid cell; (j) cell from settled amoeboid cell; (k) zoosporangium wall disintegrates and releases zoospores; (l) release of zoospores from cell cluster.

to vegetative cells (Fig. 2b). Vegetative cells were quite spherical in shape, with sizes ranging from $5-10 \mu \mathrm{m}$ in diameter.

Vegetative cells increased in size by undergoing cell division (Fig. 2c) before developing into a zoosporangium (Fig. 2d). After that, the zoospo-

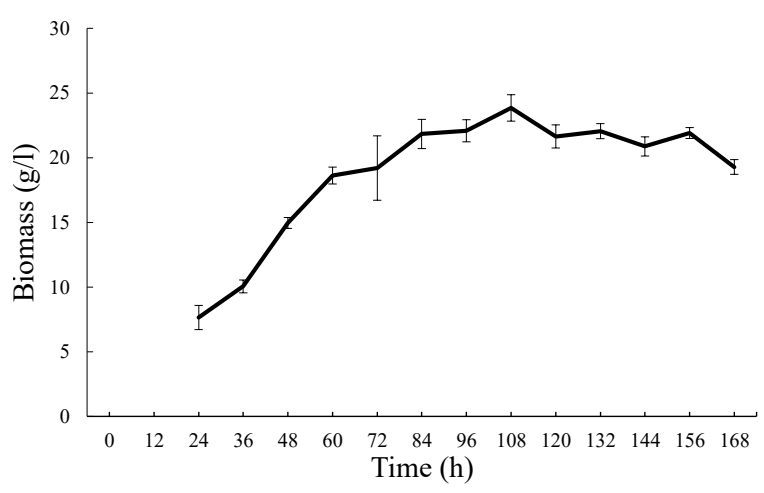

Fig. 3 Growth curve of A. limacinum BUCHAXM 122 in GYP broth for $168 \mathrm{~h}$. Cells were harvested after $24 \mathrm{~h}$.

rangium walls split or tore, releasing zoospores (Fig. $1 \mathrm{~g}$ and Fig. 2e). In some circumstances, vegetative cells underwent repeated binary division (Fig. 2f and Fig. 2g), forming cell clusters (Fig. 2h), with some cells dissociating from the cluster and converting directly to amoeboid cells (Fig. 2i). After that, amoeboid cells became spherical (Fig. 2j), developing into a zoosporangium, with the zoosporangium wall then disintegrating to release zoospores (Fig. 1h and Fig. 2k). After binary cell division, there were some cells that developed into zoosporangia and released zoospores (Fig. 2l). The total time elapsed for the vegetative cells to develop into a zoosporangium and release zoospores was approximately 10-15 h. 


\section{Biomass and fatty acid content}

A. limacinum BUCHAXM 122 cultivated in an incubator shaker resulted in a suitable growth. Their biomass increased rapidly during the first $60 \mathrm{~h}$ (log phase), reaching $18.62 \pm 0.65 \mathrm{~g} / \mathrm{l}$, with a specific growth rate of $0.03 \mathrm{~h}^{-1}$. Thereafter, biomass increased slowly from $72-84 \mathrm{~h}$, reaching a stationary phase at $84-156 \mathrm{~h}$, with highest biomass $(23.85 \pm 1.02 \mathrm{~g} / \mathrm{l})$ observed at $108 \mathrm{~h}$ (Fig. 3).

The predominant polyunsaturated fatty acid (PUFA) produced by A. limacinum BUCHAXM 122 was DHA (8.77-35.62\% TFA). Other PUFAs produced in smaller amounts were DPA $(1.15-5.84 \%$ TFA), EPA (0.00-0.09\% TFA) and ARA (0.04-0.24\% TFA). The saturated fatty acids (SFAs) tridecanoic acid (13:0), tetradecanoic acid (14:0), palmitic acid (PA, 16:0), heptadecanoic acid (17:0) and octadecanoic acid (18:0) were found in the ranges of 0.40 1.93\% TFA, 2.93-5.41\% TFA, 32.09-63.96\% TFA, $0.49-5.78 \%$ TFA and $1.07-2.02 \%$ TFA, respectively. Major fatty acid components observed in cells were DHA and palmitic acid. The content of palmitic acid from lag phase to late-stationary phase was higher than that of DHA; however, they were similar at $\log$ phase $(48 \mathrm{~h})$ and late-stationary phase $(144 \mathrm{~h})$ (Table 2).

DHA content in total fatty acids was low at the initial stages of cultivation, then rapidly increased until reaching late stationary phase. DHA content peaked at $108 \mathrm{~h}(156.91 \pm 8.69 \mathrm{mg} / \mathrm{g} \mathrm{DW}$, $30.31 \pm 5.88 \%$ TFA). DHA content was measured every $12 \mathrm{~h}$. It was found that there was an increase of DHA in parallel to biomass production every $24 \mathrm{~h}$. DHA content itself fluctuated during the period from 36-72 h. Fluctuations continued, but less strongly, from $72-108 \mathrm{~h}$. However, after $108 \mathrm{~h}$ of cultivation, DHA content became constant, or with a slight decrease.

\section{Extracellular enzyme production}

A. limacinum BUCHAXM 122 was found to produce five extracellular enzymes (Fig. 4). Activity of protease, lipase, urease, $\alpha$-glucosidase and phosphatase were detected; meanwhile, activity of agarase, cellulase, xylanase, amylase and gelatinase were not detected in this strain. The presence of extracellular protease and lipase was demonstrated by clear zone formation surrounding A. limacinum BUCHAXM 122 colonies on agar plates; this occurred within the first $24 \mathrm{~h}$ of incubation at $29-32{ }^{\circ} \mathrm{C}$. These enzymes showed the strongest activity among those detected, with the index values

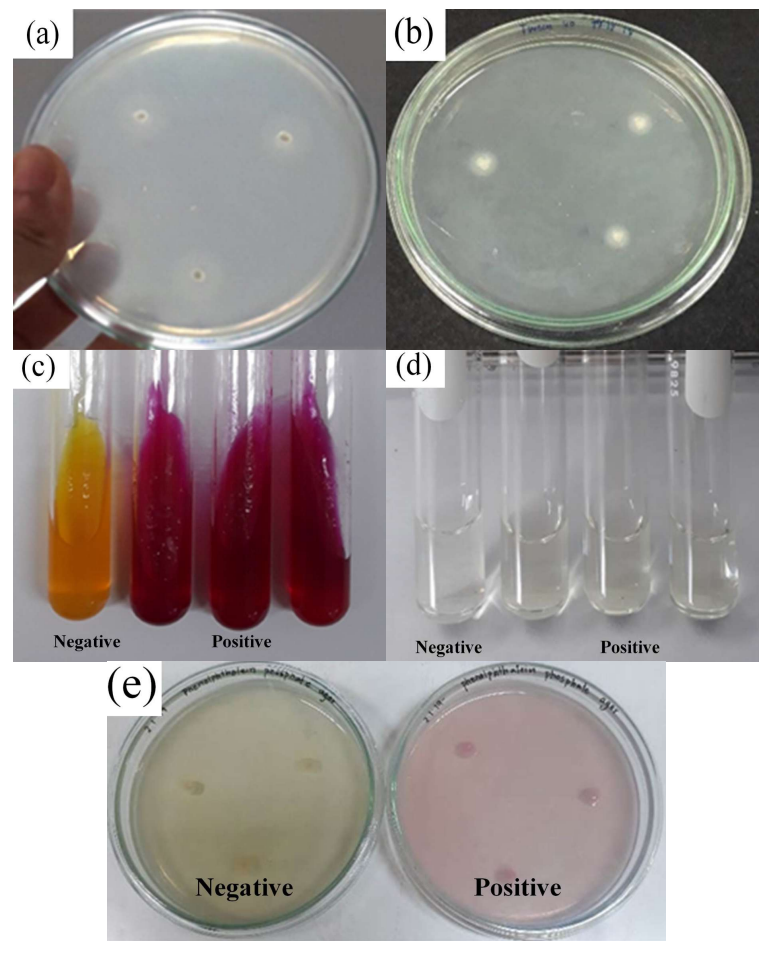

Fig. 4 Detection of extracellular enzymes produced by A. limacinum BUCHAXM 122: (a) protease; (b) lipase; (c) urease; (d) $\alpha$-glucosidase; (e) phosphatase.

between $2.14 \pm 0.16$ to $1.77 \pm 0.13$ and $1.99 \pm 0.07$ to $2.44 \pm 0.01$, respectively (Fig. $4 \mathrm{a}-\mathrm{b}$ ). The urease activity was expressed as a bright violet coloration on the slant (Fig. 4c). The $\alpha$-glucosidase activity was observed by the solution changing from colorless to pale yellow (Fig. 4d). Detection of phosphatase activity was confirmed by colonies changing from light yellow to pale pink (Fig. 4e).

\section{Elemental analysis}

Dried cells of A. limacinum BUCHAXM 122 were investigated for their elemental content. Cell composition of A. limacinum BUCHAXM 122 included 57\% carbon, $29 \%$ oxygen, 9\% hydrogen, $4 \%$ nitrogen and $1 \%$ sulfur.

\section{DISCUSSION}

Microscopic observation revealed opaque white colonies of A. limacinum strain BUCHAXM 122 on GYP agar with dominant morphological characteristics similar to those of $A$. limacinum strain SR21 [20] and A. limacinum previously reported in Thailand $[5,21]$. A. limacinum differs from other Aurantiochytrium species in its characteristic feature of colony margins and amoeboid cells. Undulating 
Table 2 Fatty acid profile of $A$. limacinum BUCHAXM 122 cultured for $168 \mathrm{~h}$.

\begin{tabular}{|c|c|c|c|c|c|c|c|c|}
\hline \multirow{2}{*}{ Fatty acid } & & \multicolumn{7}{|c|}{ Time (h) } \\
\hline & & 24 & 48 & 72 & 96 & 120 & 144 & 168 \\
\hline \multirow{2}{*}{$12: 0$} & $\mathrm{mg} / \mathrm{g} \mathrm{DW}$ & $0.21 \pm 0.08$ & $0.47 \pm 0.00$ & $0.67 \pm 0.05$ & $0.73 \pm 0.01$ & $0.66 \pm 0.12$ & $0.61 \pm 0.14$ & $0.67 \pm 0.09$ \\
\hline & $\%$ TFA & $0.19 \pm 0.07$ & $0.12 \pm 0.00$ & $0.16 \pm 0.02$ & $0.15 \pm 0.02$ & $0.13 \pm 0.05$ & $0.14 \pm 0.03$ & $0.12 \pm 0.00$ \\
\hline \multirow{2}{*}{$13: 0$} & $\mathrm{mg} / \mathrm{g} \mathrm{DW}$ & $2.10 \pm 0.45$ & $2.43 \pm 0.19$ & $2.11 \pm 0.14$ & $2.17 \pm 0.37$ & $2.29 \pm 0.15$ & $2.15 \pm 0.23$ & $2.24 \pm 0.13$ \\
\hline & $\%$ TFA & $1.93 \pm 0.44$ & $0.62 \pm 0.06$ & $0.50 \pm 0.06$ & $0.44 \pm 0.04$ & $0.45 \pm 0.05$ & $0.50 \pm 0.06$ & $0.40 \pm 0.03$ \\
\hline \multirow{2}{*}{$14: 0$} & $\mathrm{mg} / \mathrm{g} \mathrm{DW}$ & $3.62 \pm 0.44$ & $11.48 \pm 0.93$ & $15.95 \pm 3.07$ & $18.95 \pm 4.57$ & $17.37 \pm 1.28$ & $16.28 \pm 0.12$ & $20.27 \pm 2.31$ \\
\hline & $\%$ TFA & $3.30 \pm 0.32$ & $2.93 \pm 0.31$ & $3.75 \pm 0.07$ & $3.81 \pm 0.61$ & $3.39 \pm 0.32$ & $3.80 \pm 0.01$ & $3.63 \pm 0.07$ \\
\hline \multirow{2}{*}{$15: 0$} & $\mathrm{mg} / \mathrm{g} \mathrm{DW}$ & $16.27 \pm 1.15$ & $40.95 \pm 0.76$ & $25.57 \pm 4.71$ & $19.77 \pm 4.13$ & $19.80 \pm 0.32$ & $17.55 \pm 0.57$ & $19.82 \pm 0.62$ \\
\hline & $\%$ TFA & $14.93 \pm 1.84$ & $10.45 \pm 0.05$ & $6.02 \pm 0.06$ & $3.98 \pm 0.49$ & $3.89 \pm 0.61$ & $4.09 \pm 0.17$ & $3.60 \pm 0.63$ \\
\hline \multirow{2}{*}{$16: 0$} & $\mathrm{mg} / \mathrm{g} \mathrm{DW}$ & $45.50 \pm 4.05$ & $133.15 \pm 10.28$ & $171.59 \pm 27.86$ & $211.62 \pm 24.56$ & $185.95 \pm 10.17$ & $160.36 \pm 7.93$ & $199.63 \pm 15.94$ \\
\hline & $\%$ TFA & $41.62 \pm 3.77$ & $34.02 \pm 3.46$ & $40.49 \pm 0.64$ & $42.87 \pm 1.06$ & $36.38 \pm 4.18$ & $37.42 \pm 2.21$ & $35.89 \pm 2.03$ \\
\hline \multirow{2}{*}{$16: 1$} & $\mathrm{mg} / \mathrm{g} \mathrm{DW}$ & $0.47 \pm 0.10$ & $1.51 \pm 0.27$ & $2.18 \pm 0.17$ & $2.33 \pm 0.36$ & $2.38 \pm 0.72$ & $2.49 \pm 0.59$ & $2.13 \pm 0.33$ \\
\hline & $\%$ TFA & $0.43 \pm 0.05$ & $0.38 \pm 0.06$ & $0.52 \pm 0.06$ & $0.48 \pm 0.12$ & $0.45 \pm 0.08$ & $0.58 \pm 0.14$ & $0.39 \pm 0.12$ \\
\hline \multirow{2}{*}{$17: 0$} & $\mathrm{mg} / \mathrm{g}$ DW & $5.11 \pm 0.41$ & $10.77 \pm 0.63$ & $7.20 \pm 1.35$ & $5.96 \pm 0.42$ & $6.44 \pm 0.20$ & $5.21 \pm 0.14$ & $5.95 \pm 0.32$ \\
\hline & \% TFA & $4.69 \pm 0.59$ & $2.74 \pm 0.10$ & $1.69 \pm 0.02$ & $1.21 \pm 0.03$ & $1.26 \pm 0.18$ & $1.22 \pm 0.04$ & $1.08 \pm 0.22$ \\
\hline \multirow{2}{*}{$17: 1$} & $\mathrm{mg} / \mathrm{g} \mathrm{DW}$ & $0.15 \pm 0.02$ & $0.13 \pm 0.06$ & $0.58 \pm 0.67$ & $0.81 \pm 0.07$ & $0.80 \pm 0.44$ & $0.26 \pm 0.23$ & $0.63 \pm 0.37$ \\
\hline & $\%$ TFA & $0.14 \pm 0.01$ & $0.03 \pm 0.01$ & $0.16 \pm 0.21$ & $0.16 \pm 0.00$ & $0.15 \pm 0.07$ & $0.06 \pm 0.05$ & $0.11 \pm 0.06$ \\
\hline \multirow{2}{*}{$18: 0$} & $\mathrm{mg} / \mathrm{g} \mathrm{DW}$ & $1.99 \pm 0.25$ & $4.51 \pm 0.01$ & $5.81 \pm 0.95$ & $5.86 \pm 0.35$ & $6.05 \pm 0.92$ & $5.28 \pm 0.49$ & $5.94 \pm 0.10$ \\
\hline & $\%$ TFA & $1.81 \pm 0.17$ & $1.15 \pm 0.03$ & $1.37 \pm 0.02$ & $1.19 \pm 0.04$ & $1.17 \pm 0.01$ & $1.23 \pm 0.10$ & $1.07 \pm 0.13$ \\
\hline \multirow{2}{*}{$18: 1$} & $\mathrm{mg} / \mathrm{g} \mathrm{DW}$ & $0.68 \pm 0.14$ & $1.55 \pm 0.04$ & $2.14 \pm 0.09$ & $1.06 \pm 0.57$ & $1.98 \pm 0.19$ & $1.43 \pm 0.48$ & $1.13 \pm 0.44$ \\
\hline & $\%$ TFA & $0.62 \pm 0.06$ & $0.40 \pm 0.00$ & $0.51 \pm 0.08$ & $0.22 \pm 0.14$ & $0.39 \pm 0.11$ & $0.33 \pm 0.11$ & $0.21 \pm 0.11$ \\
\hline \multirow{2}{*}{$18: 3 n-6$} & $\mathrm{mg} / \mathrm{g} \mathrm{DW}$ & $0.09 \pm 0.01$ & $0.28 \pm 0.02$ & $0.34 \pm 0.17$ & $0.48 \pm 0.27$ & $0.35 \pm 0.19$ & $0.37 \pm 0.24$ & $0.33 \pm 0.03$ \\
\hline & $\%$ TFA & $0.08 \pm 0.00$ & $0.07 \pm 0.01$ & $0.09 \pm 0.06$ & $0.10 \pm 0.07$ & $0.07 \pm 0.05$ & $0.09 \pm 0.06$ & $0.06 \pm 0.00$ \\
\hline \multirow{2}{*}{$18: 3 n-3$} & $\mathrm{mg} / \mathrm{g}$ DW & $0.22 \pm 0.02$ & $0.71 \pm 0.02$ & $0.78 \pm 0.08$ & $0.39 \pm 0.48$ & $0.67 \pm 0.15$ & $0.70 \pm 0.30$ & $0.55 \pm 0.06$ \\
\hline & $\%$ TFA & $0.20 \pm 0.00$ & $0.18 \pm 0.00$ & $0.19 \pm 0.06$ & $0.09 \pm 0.11$ & $0.14 \pm 0.06$ & $0.16 \pm 0.07$ & $0.10 \pm 0.03$ \\
\hline \multirow{2}{*}{$20: 0$} & $\mathrm{mg} / \mathrm{g} \mathrm{DW}$ & $0.12 \pm 0.03$ & $0.37 \pm 0.03$ & $0.65 \pm 0.23$ & $0.71 \pm 0.12$ & $0.56 \pm 0.20$ & $0.66 \pm 0.16$ & $0.51 \pm 0.15$ \\
\hline & $\%$ TFA & $0.11 \pm 0.01$ & $0.10 \pm 0.01$ & $0.16 \pm 0.09$ & $0.15 \pm 0.04$ & $0.12 \pm 0.06$ & $0.15 \pm 0.03$ & $0.10 \pm 0.04$ \\
\hline \multirow{2}{*}{$20: 2$} & $\mathrm{mg} / \mathrm{g} \mathrm{DW}$ & $0.00 \pm 0.00$ & $0.00 \pm 0.00$ & $0.00 \pm 0.00$ & $0.00 \pm 0.00$ & $0.00 \pm 0.00$ & $0.00 \pm 0.00$ & $0.00 \pm 0.00$ \\
\hline & \% TFA & $0.00 \pm 0.00$ & $0.00 \pm 0.00$ & $0.00 \pm 0.00$ & $0.00 \pm 0.00$ & $0.00 \pm 0.00$ & $0.00 \pm 0.00$ & $0.00 \pm 0.00$ \\
\hline \multirow{2}{*}{$20: 3$} & $\mathrm{mg} / \mathrm{g}$ DW & $0.07 \pm 0.03$ & $0.30 \pm 0.04$ & $0.33 \pm 0.04$ & $0.32 \pm 0.03$ & $0.29 \pm 0.01$ & $0.38 \pm 0.06$ & $0.26 \pm 0.07$ \\
\hline & $\%$ TFA & $0.06 \pm 0.02$ & $0.08 \pm 0.01$ & $0.08 \pm 0.01$ & $0.07 \pm 0.00$ & $0.06 \pm 0.01$ & $0.09 \pm 0.01$ & $0.05 \pm 0.02$ \\
\hline \multirow{2}{*}{$20: 4$} & $\mathrm{mg} / \mathrm{g} \mathrm{DW}$ & $0.09 \pm 0.03$ & $0.43 \pm 0.03$ & $0.51 \pm 0.12$ & $0.68 \pm 0.13$ & $0.77 \pm 0.05$ & $0.72 \pm 0.13$ & $0.55 \pm 0.15$ \\
\hline & $\%$ TFA & $0.08 \pm 0.02$ & $0.11 \pm 0.00$ & $0.12 \pm 0.01$ & $0.14 \pm 0.01$ & $0.15 \pm 0.02$ & $0.17 \pm 0.03$ & $0.10 \pm 0.04$ \\
\hline \multirow{2}{*}{$20: 5$} & $\mathrm{mg} / \mathrm{g}$ DW & $0.02 \pm 0.03$ & $0.00 \pm 0.00$ & $0.00 \pm 0.00$ & $0.00 \pm 0.00$ & $0.00 \pm 0.00$ & $0.00 \pm 0.00$ & $0.00 \pm 0.00$ \\
\hline & \% TFA & $0.02 \pm 0.03$ & $0.00 \pm 0.00$ & $0.00 \pm 0.00$ & $0.00 \pm 0.00$ & $0.00 \pm 0.00$ & $0.00 \pm 0.00$ & $0.00 \pm 0.00$ \\
\hline \multirow{2}{*}{$22: 1$} & $\mathrm{mg} / \mathrm{g}$ DW & $0.24 \pm 0.09$ & $1.37 \pm 0.01$ & $1.62 \pm 0.29$ & $2.34 \pm 0.41$ & $2.89 \pm 0.43$ & $3.15 \pm 0.15$ & $3.34 \pm 0.05$ \\
\hline & $\%$ TFA & $0.21 \pm 0.06$ & $0.35 \pm 0.01$ & $0.38 \pm 0.00$ & $0.47 \pm 0.04$ & $0.56 \pm 0.01$ & $0.74 \pm 0.03$ & $0.60 \pm 0.08$ \\
\hline \multirow{2}{*}{$22: 5$} & $\mathrm{mg} / \mathrm{g} \mathrm{DW}$ & $4.09 \pm 1.27$ & $20.83 \pm 2.25$ & $19.89 \pm 2.05$ & $5.06 \pm 8.67$ & $18.78 \pm 0.32$ & $25.03 \pm 1.69$ & $23.18 \pm 2.81$ \\
\hline & $\%$ TFA & $3.68 \pm 0.74$ & $5.32 \pm 0.71$ & $4.73 \pm 0.39$ & $1.15 \pm 1.97$ & $3.69 \pm 0.58$ & $5.84 \pm 0.45$ & $4.25 \pm 1.15$ \\
\hline \multirow{2}{*}{$22: 6$} & $\mathrm{mg} / \mathrm{g}$ DW & $21.60 \pm 8.05$ & $125.34 \pm 0.28$ & $133.52 \pm 10.70$ & $120.54 \pm 14.42$ & $129.28 \pm 2.97$ & $152.68 \pm 0.04$ & $148.93 \pm 10.19$ \\
\hline & $\%$ TFA & $19.40 \pm 5.30$ & $31.99 \pm 0.83$ & $31.85 \pm 3.44$ & $24.41 \pm 0.70$ & $25.39 \pm 3.80$ & $35.62 \pm 0.36$ & $27.15 \pm 5.84$ \\
\hline Other & $\mathrm{mg} / \mathrm{g}$ DW & $7.22 \pm 1.75$ & $35.42 \pm 21.38$ & $33.14 \pm 24.39$ & $93.08 \pm 6.76$ & $120.08 \pm 64.88$ & $33.38 \pm 12.97$ & $122.93 \pm 69.67$ \\
\hline Other & $\%$ TFA & $6.52 \pm 0.88$ & $8.95 \pm 5.32$ & $7.22 \pm 4.98$ & $18.91 \pm 0.40$ & $22.16 \pm 9.94$ & $7.77 \pm 2.93$ & $21.07 \pm 10.49$ \\
\hline Total & $\mathrm{mg} / \mathrm{g}$ DW & $109.84 \pm 12.72$ & $392.01 \pm 9.15$ & $424.57 \pm 74.82$ & $492.85 \pm 45.75$ & $517.37 \pm 81.98$ & $428.71 \pm 4.31$ & $559.02 \pm 73.57$ \\
\hline lotal & $\%$ TFA & 100 & 100 & 100 & 100 & 100 & 100 & 100 \\
\hline
\end{tabular}

colony margins and large number of amoeboid cells are distinctive characteristics of A. limacinum [22]; these characteristics were also found in A. limacinum strain BUCHAXM 122. Rough colony margins were probably a result of creeping of amoeboid cells. Vegetative cell size of $A$. limacinum strain BUCHAXM $122(5-10 \mu \mathrm{m})$ was smaller than $A$. limacinum SR21 (7-15 $\mu \mathrm{m})$ [20] and A. limacinum (5-20 $\mu \mathrm{m})$ [21].
This study showed that $A$. limacinum BUCHAXM 122 released zoospores from zoosporangium walls in two forms: some zoospores that split after being released, as previously reported [22]; other zoospores disintegrated after release, as reported by other authors [20]. The life cycle of $A$. limacinum BUCHAXM 122 was shown to be approximately 24 h. This study, therefore, suggests that cells 
be cultivated for $48 \mathrm{~h}$ prior to an inoculum being prepared. This is because most cells during this log phase are vegetative cells, quite active and capable of producing large amounts of cells. It would, thus, be impractical to impede this period of maximum cell development.

When A. limacinum BUCHAXM 122 was cultured with GYP medium, it provided a maximum biomass yield of $23.85 \mathrm{~g} / \mathrm{l}$, similar to A. limacinum $(20.71 \mathrm{~g} / \mathrm{l})$ [5]. Major fatty acids were palmitic acid and DHA, accounting for $32.09-63.96 \%$ and 8.77-35.62\% TFA, respectively. These results agree well with published reports for eleven strains of Aurantiochytrium spp., which were found to contain palmitic acid in a range of $39.67-48.37 \%$ and DHA in a range of $22.13-60.33 \%$ TFA [23]. We found that palmitic acid forms a higher proportion of TFA than DHA; it was also higher in the stationary phase of Aurantiochytrium sp. KRS101 [24]. Palmitic acid is a saturated fatty acid, the consumption of which is often related to increased coronary heart disease risk. One explanation is that palmitic acid is converted to the monounsaturated fatty acid (18:1) by the PUFA synthetic pathway and thus accounts for the LDL-cholesterol raising effect of palmitic acid [25]. Therefore, using A. limacinum BUCHAXM 122 as an alternative fatty acid source must be carefully done, respecting human health issues.

In this study, DHA content during the stationary phase (96-108 h) was higher than in early growth phase $(24-96 \mathrm{~h})$. This is possibly due to creation of lipid bodies occurring at the end of the life cycle and increasing total fatty acids/cell volume in proportion to growth and development of the lipid body [26]. At late-stationary phase $(120 \mathrm{~h})$, production of DHA was rather stable with a slight decrease trend, possibly due to degeneration and abnormal cells [24]. This indicates that the appropriate harvest time was between 96 and $108 \mathrm{~h}$ after culturing.

DHA content in A. limacinum BUCHAXM 122 was higher than in Schizochytrium limacinum SR21 (14.72-18.38\% TFA) [27], Aurantiochytrium sp. KRS101 (19.88\% TFA) [28] and Aurantiochytrium 4W-1b (27.9\% TFA) [29]. The DHA content was also higher than those reported for genus Thraustochytrium (T. striatum) (0.8-6\% TFA) [30] and Thraustochytrium sp. strain 004 (2.7\% TFA) [31]. In addition, the DHA content in A. limacinum BUCHAXM 122 was higher than in other species of microalgae such as Phaeodactylum tricornutum (1.65-4.89\% TFA) [32], Alexandrium sanguinea (23.8\% TFA) and Chlorella ellipsoidea (3.1\%
TFA) [33]. This indicates that A. limacinum BUCHAXM 122 has high potential as a source of polyunsaturated fatty acids, particularly for industrial production of DHA. Since this strain shows optimum potential to maximize biomass and DHA production, it is highly applicable for aquaculture and/or further commercial uses.

The content of other polyunsaturated fatty acids, such ARA, EPA and DPA in A. limacinum BUCHAXM 122 was lower than in Parietichtrium sarkarianum [21], Ulkenia [31] and Thraustochytrium [21, 31]. Although PUFA amounts found in A. limacinum BUCHAXM 122 were less than in other microorganisms, an advantage remains for its future use: PUFA from thraustochytrids, especially Aurantiochytrium sp. and Schizochytrium sp., are now certified safe for human consumption. As there is interest in making DHA-rich oil products, including products for pregnant and nursing women and bio-ingredients for inclusion in many food products [1], PUFA produced from A. limacinum BUCHAXM 122 has high potential.

Five extracellular enzymes including protease, lipase, urease, $\alpha$-glucosidase, and phosphatase were produced by A. limacinum BUCHAXM 122, consistent with previous reports for other species of Aurantiochytrium $[23,34]$ and also for Shizochytrium and Thraustochytrium [34]. Similar to the ecosystem in which A. limacinum is found, phosphatase, $\beta$ glucosidase and protease are also found in the bacteria such as Planctomycetes, Chloroflexi, Roseobacter, Alteromonas and Pseudoalteromonas [35]. However, most bacteria that live in seawater, sediment, plants and animals produce lipase phosphatase and protease, and a few produce urease [36]. Such information shows that the diversity of extracellular enzymes is related to the type of microorganisms present, which in turn, is related to habitat [23]. These degradative enzymes likely play an important role in the environmental material cycle and marine microbial cycle. Protease plays an important part of the nitrogen cycle and has a regulatory role in nature. Urea from protein degradation is hydrolyzed to ammonia by urease. Aurantiochytrium has the ability to benefit from urea as a source of nitrogen, resulting in high production of biomass and lipid content [34]. Lipase is any enzyme that catalyzes the hydrolysis of lipids. It contributes to the degradation and assimilation of lipid nutrients from their marine environment, as well as generating antimicrobial compounds (lysophospholipids) beneficial for competition with bacteria over lipid nutrients [37]. A previous study reported that $\alpha$ - 
glucosidase was involved through a bacterial role in the carbon cycle of mangrove sediments. This occurred through degradation of carbohydrates, which are common structural and storage polymers in aquatic organisms and are critical energy components of food webs [38]. Phosphatase has been reported to be able to mineralize organic phosphates into inorganic phosphates, and may play a role in the phosphorus cycle by utilizing phosphorus released from dissolved organic phosphorus in seawater [34]. The isolates investigated in this study showed diversified degradative enzymatic patterns. This study suggests that $A$. limacinum BUCHAXM 122 could be optimized as an alternative for wastewater treatment, particularly for coastal aquaculture.

\section{CONCLUSION}

In summary, this study shows that $A$. limacinum BUCHAXM 122 is a promising candidate source for polyunsaturated fatty acid production. It could be used as an alternate DHA source, a substitute for fish oil in aquaculture, animal feeds, human foods, cosmetics, pharmaceuticals and as a sustainable energy source for biodiesel production. Its biological understanding can be used for product improvement in processes requiring fermentation. It produces numerous lipid bodies every $24 \mathrm{~h}$ of life cycle; therefore, harvesting of cells can be appropriate every $24 \mathrm{~h}$ during $72-108 \mathrm{~h}$ of cultivation, when biomass $(23.85 \pm 1.02 \mathrm{~g} / \mathrm{l})$ and DHA $(30.31 \pm 5.88 \%$ TFA $)$ are highest. A. limacinum BUCHAXM 122 produces the extracellular enzymes protease, lipase, urease, $\alpha$-glucosidase and phosphatase, which are all beneficial to the environment. However further research on an appropriate substrate (to produce more enzyme, one should optimize culturing condition or adding some inducer, not the substrate) is needed in order to produce larger quantities of enzymes.

Acknowledgements: This research was funded by the Faculty of Science, Burapha University. We are grateful for the technical assistance from the staff of the Major of Environment Science and Department of Aquatic Science, Faculty of Science, Burapha University, Chon Buri, Thailand.

\section{REFERENCES}

1. Marchan LF, Chang KJL, Nichols PD, Mitchell WJ, Polglase JL, Gutierrez T (2018) Taxonomy, ecology and biotechnological applications of thraustochytrids: A review. Biotechnol Adv 36, 26-46.

2. Raghukumar S (2002) Ecology of the marine protists, the Labyrinthulomycetes (Thraustochytrids and Labyrinthulids). Eur J Protistol 38, 127-145.
3. Gupta A, Barrow CJ, Puri M (2012) Omega-3 biotechnology: Thraustochytrids as a novel source of omega-3 oils. Biotechnol Adv 30, 1733-1745.

4. Horrocks LA, Yeo YK (1999) Health benefits of docosahexaenoic acid (DHA). Pharmacol Res 40, 211-225.

5. Jaritkhuan S, Suanjit S (2018) Species diversity and polyunsaturated fatty acid content of thraustochytrids from fallen mangrove leaves in Chon Buri province, Thailand. Agric Nat Resour 52, 24-32.

6. Ye J, Liu M, He M, Ye Y, Huang J (2019) Illustrating and enhancing the biosynthesis of astaxanthin and docosahexaenoic acid in Aurantiochytrium sp. SK4. Mar Drugs 17, ID 45.

7. Allison SD, Vitousek PM (2005) Responses of extracellular enzymes to simple and complex nutrient inputs. Soil Biol Biochem 37, 937-944.

8. Bumbak F, Cook S, Zachleder V, Hauser S, Kovar $\mathrm{K}$ (2011) Best practices in heterotrophic high-celldensity microalgal processes: achievements, potential and possible limitations. Appl Microbiol Biotechnol 91, 31-46.

9. Shimizu S, Kawashima H, Shinmen Y, Akimoto K, Yamada H (1988) Production of eicosapentaenoic acid by Mortierella fungi. J Am Oil Chem Soc 65, 1455-1459.

10. Rajeswari S, Jaiganesh R, Muthukumar R, Jaganathan MK (2016) Isolation and characterization of an agarase producing bacteria from marine sediment. Int $J$ ChemTech Res 9, 437-446.

11. Gorems W, Alemu T (2014) Production and optimization of cellulase from Trichodrma isolates under liquid state fermentation (LSF). SINET: Ethiop J Sci 37, 131-142.

12. Sae-Lee N (2007) The production of fungal mannanase, cellulase and xylanase using palm kernel meal as a substrate. Walailak $J$ Sci Tech 4, 67-82.

13. Singh V, Sharma R, Sharma P (2015) Isolation, screening and optimization of amylase producing Bacillus sp. from soil. Asian Pac J Health Sci 2, 86-93.

14. Nadeem M, Qazi JI, Baig S (2010) Enhanced production of alkaline protease by a mutant of Bacillus licheniformis N-2 for dehairing. Braz Arch Biol Tech 53, 1015-1025.

15. Rai B, Shrestha A, Sharma S, Joshi J (2014) Screening, optimization and process scale up for pilot scale production of lipase by Aspergillus niger. $J$ Biomed Biotechnol 2, 54-59.

16. Arellano-Carbajal F, Olmos-Soto J (2002) Thermostable $\alpha$-1,4- and $\alpha$-1,6-glucosidase enzymes from Bacillus sp. isolated from a marine environment. World J Microbiol Biotechnol 18, 791-795.

17. Barrow GI, Feltham RKA (1993) Cowan and Steel's Manual for the Identification of Medical Bacteria, 3rd edn, Cambridge Univ Press, Cambridge. 
18. Vuye A, Pijck J (1973) Urease activity of enterobacteriaceae: which medium to choose. Appl Microbiol 26, 850-854.

19. Harley JP, Prescott LM (2002) Laboratory Exercises in Microbiology, 5th edn, McGraw-Hill Companies, New York.

20. Honda D, Yokochi T, Nakahara T, Erata M, Higashihara T (1998) Schizochytrium limacinum sp. nov., a new thraustochytrid from a mangrove area in the west Pacific Ocean. Mycol Res 102, 439-448.

21. Unagul P, Suetrong S, Preedanon S, Klaysuban A, Gundool W, Suriyachadkun C, Sakayaroj J (2017) Isolation, fatty acid profiles and cryopreservation of marine thraustochytrids from mangrove habitats in Thailand. Bot Mar 60, 363-379.

22. Manikan V, Nazir MYM, Kalil MS, Isa MHM, Kader AJA, Yusoff WMW, Hamid AA (2015) A new strain of docosahexaenoic acid producing microalga from Malaysian coastal waters. Algal Res 9, 40-47.

23. Jaseera KV, Kaladharan P, Vijayan KK, Sandhya SV, Antony ML, Pradeep MA (2019) Isolation and phylogenetic identification of heterotrophic thraustochytrids from mangrove habitats along the southwest coast of India and prospecting their PUFA accumulation. J Appl Phycol 31, 1057-1068.

24. Velmurugan N, Sathishkumar Y, Yim SS, Lee YS, Park MS, Yang JW, Jeong KJ (2014) Study of cellular development and intracellular lipid bodies accumulation in the thraustochytrid Aurantiochytrium sp. KRS101. Bioresour Technol 161, 149-154.

25. Brody T (1999) Nutritional Biochemistry, 2nd edn, Academic Press, San Diego.

26. Morita E, Kumon Y, Nakahara T, Kagiwada S, Noguchi $\mathrm{T}$ (2006) Docosahexaenoic acid production and lipidbody formation in Schizochytrium limacinum SR21. Mar Biotechnol 8, 319-327.

27. Patil KP, Gogate PR (2015) Improved synthesis of docosahexaenoic acid (DHA) using Schizochytrium limacinum SR21 and sustainable media. Chem Eng $J$ 268, 187-196.

28. Hong WK, Rairakhwada D, Seo PS, Park SY, Hur BK, Kim CH, Seo JW (2011) Production of lipids containing high levels of docosahexaenoic acid by a newly isolated microalga, Aurantiochytrium sp. KRS101. Appl Biochem Biotechnol 164, 1468-1480.

29. Nakazawa A, Matsuura $H$, Kose $R$, Ito K, Ueda M, Honda D, Inouye I, Kaya K, et al (2012) Optimization of biomass and fatty acid production by Aurantiochytrium sp. strain 4W-1b. Procedia Environ Sci 15, 27-33.

30. Shene C, Garcés M, Vergara D, Peña J, Claverol S, Rubilar M, Leyton A (2019) Production of lipids and proteome variation in a Chilean Thraustochytrium striatum strain cultured under different growth conditions. Mar Biotechnol 21, 99-110.

31. Lee Chang KJ, Nichols CM, Blackburn SI, Dunstan GA, Koutoulis A, Nichols PD (2014) Comparison of thraustochytrids Aurantiochytrium sp., Schizochytrium sp., Thraustochytrium sp., and Ulkenia sp. for production of biodiesel, long-chain omega3 oils, and exopolysaccharide. Mar Biotechnol 16, 396-411.

32. Patel A, Matsakas L, Hrůzová K, Rova U, Christakopoulos P (2019) Biosynthesis of nutraceutical fatty acids by the oleaginous marine microalgae Phaeodactylum tricornutum utilizing hydrolysates from organosolv-pretreated birch and spruce biomass. Mar Drugs 17, ID 119.

33. Suh SS, Kim SJ, Hwang J, Park M, Lee TK, Kil EJ, Lee $S$ (2015) Fatty acid methyl ester profiles and nutritive values of 20 marine microalgae in Korea. Asian Pac $J$ Trop Med 8, 191-196.

34. Taoka Y, Nagano N, Okita Y, Izumida H, Sugimoto S, Hayashi M (2009) Extracellular enzymes produced by marine eukaryotes, thraustochytrids. Biosci Biotechnol Biochem 73, 180-182.

35. Li Y, Sun L-L, Sun Y-Y, Cha Q-Q, Li C-Y, Zhao D-L, Song X-Y, Wang M, et al (2019) Extracellular enzyme activity and its implications for organic matter cycling in northern Chinese marginal seas. Front Microbiol 10, ID 2137.

36. Fenice M, Gallo AM, Juarez-Jimenez B, GonzalezLopez J (2007) Screening for extracellular enzyme activity by bacteria isolated from samples collected in the Tyrrhenian Sea. Ann Microbiol 57, 93-99.

37. Ishibashi Y, Aoki K, Okino N, Hayashi M, Ito M (2019) A thraustochytrid-specific lipase/phospholipase with unique positional specificity contributes to microbial competition and fatty acid acquisition from the environment. Sci Rep 9, ID 16357.

38. Liu HJ, Tian Y, Zheng TL, Yan CL, Hong HS (2008) Studies of glucosidase activities from surface sediments in mangrove swamp. J Exp Mar Biol Ecol 367, 111-117. 